\title{
Seasonal effects on the nutritive value of the natural food of three omnivorous fish (Oreochromis niloticus, Sarotherodon galilaeus, Citharinus citharus) in Batamani Pond (Mali, West Africa)
}

\author{
M.C. Blé(1), R. Arfi ${ }^{(2)}$
}

Received April 15, 2009 / Reçu le 15 avril 2009

Revised July 13, 2009 / Révisé le 13 juillet 2009

Accepted September 23, 2009 / Accepté le 23 septembre 2009

Key-words: $\quad$ The chemical composition of the stomach contents and the digestibility of omnivorous fish, natural food, nutritive value, climate, Batamani Pond, Mali

\section{ABSTRACT} organic matter, proteins and energy of three planktivorous fish species (Oreochromis niloticus, Sarotherodon galilaeus and Citharinus citharus) were studied in Batamani Pond (Mali, West Africa) during the dry and wet seasons. The diet contents of $O$. niloticus and $S$. galilaeus presented high levels of organic matter and proteins during the wet season (ashfree dry weight (AFDW): $753 \mathrm{mg} \cdot \mathrm{g}^{-1} \mathrm{dw}$ and $703 \mathrm{mg} \cdot \mathrm{g}^{-1} \mathrm{dw}$, protein contents: $479 \mathrm{mg} \cdot \mathrm{g}^{-1}$ AFDW and $449 \mathrm{mg} \cdot \mathrm{g}^{-1}$ AFDW, respectively). In the dry season, the chemical composition of the food was characterized by high proportions of inorganic material $(73 \%$ and $68 \%$ for 0 . niloticus and S. galilaeus, respectively). The chemical composition of the food of C. citharus was characterized by low seasonal variation. The levels of AFDW (396-461 mg. ${ }^{-1} \mathrm{dw}$ ) and proteins $\left(65-86 \mathrm{mg} \cdot \mathrm{g}^{-1}\right.$ AFDW) in its diet were generally low, reflecting a high proportion of mineral content. During the wet season, the digestibility of AFDW (52\% and $58 \%$ ), total amino acids (68\% and $76 \%$ ) and energy (63\% and 56\%) increased significantly for $O$. niloticus and S. galilaeus, respectively. Nutrient and energy digestibility for $C$. citharus showed no significant seasonal variations (AFDW: $36-45 \%$; total amino acids: $57-64 \%$; energy: $31-39 \%$ ). The marked seasonal character of the pond, in terms of both hydrology and trophic conditions, had a low impact on the availability and quality of nutritive resources for the two tilapia species $O$. niloticus and $S$. galilaeus, while $C$. citharus appears to have the capacity to adapt its regime to the available food quality, whatever the season.

(1) CRO (Centre de Recherches Océanologiques), Département Aquaculture, BP V 18 Abidjan, Côte d'Ivoire, blecel@hotmail.com

(2) IRD (Institut de Recherche pour le Développement), LOPB, Centre d'Océanographie de Marseille, Faculté des Sciences de Luminy, 13009 Marseille, France, robert.arfi@univmed.fr 


\section{RÉSUMÉ}

Effets de la saison sur la valeur nutritive de l'alimentation naturelle de trois poissons omnivores (Oreochromis niloticus, Sarotherodon galilaeus, Citharinus citharus) dans la mare de Batamani (Mali, Afrique de l'Ouest)

\begin{tabular}{|c|c|}
\hline $\begin{array}{l}\text { lots-clés : } \\
\text { oissons } \\
\text { nnivores, } \\
\text { imentation } \\
\text { turelle, } \\
\text { aleur nutritive, } \\
\text { imat, } \\
\text { are de } \\
\text { atamani, } \\
\text { ali }\end{array}$ & $\begin{array}{l}\text { La composition chimique des contenus stomacaux et la digestibilité de la matière } \\
\text { organique, des protéines et de l'énergie chez trois espèces de poissons plancto- } \\
\text { phages (Oreochromis niloticus, Sarotherodon galilaeus et Citharinus citharus) de la } \\
\text { mare de Batamani (Mali, Afrique de l'Ouest) ont été déterminées en saison sèche } \\
\text { et humide. Chez Oreochromis niloticus et Sarotherodon galilaeus, les contenus } \\
\text { stomacaux présentent des quantités élevées en matières organiques et en pro- } \\
\text { téines au cours de la saison humide (matière organique totale }: 753 \mathrm{mg} \cdot \mathrm{g}^{-1} \text { poids } \\
\mathrm{sec} \text { et } 703 \mathrm{mg} \cdot \mathrm{g}^{-1} \text { poids sec, protéines : } 479 \mathrm{mg} \cdot \mathrm{g}^{-1} \text { de matière organique totale } \\
\text { et } 449 \mathrm{mg} \cdot \mathrm{g}^{-1} \text { de matière organique totale respectivement). En saison sèche, la } \\
\text { composition chimique de l'alimentation est caractérisée par de fortes quantités de } \\
\text { minéraux ( } 73 \% \text { et } 68 \% \text { respectivement chez ces deux espèces). Chez Citharinus } \\
\text { citharus, les teneurs en matière organique représentent } 461 \mathrm{mg} \cdot \mathrm{g}^{-1} \text { de poids sec } \\
\text { en saison humide et la composition chimique de son alimentation présente dans } \\
\text { l'ensemble une faible variation saisonnière. Chez } O \text {. niloticus et } S \text {. galilaeus, les } \\
\text { coefficients de digestibilité des matières organiques (52 \% et } 58 \% \text { ), des acides } \\
\text { aminés totaux (68 \% et } 76 \% \text { et de l'énergie (63 \% et } 56 \% \text { ) augmentent signifi- } \\
\text { cativement pendant la saison humide. Chez C. citharus, la digestibilité des nutri- } \\
\text { ments et de l'énergie est peu variable d'une saison à l'autre (matière organique : } \\
30-45 \% \text {; acides aminés totaux: } 57-64 \% \text {; énergie : } 31-39 \% \text { ). Le caractère sai- } \\
\text { sonnier des conditions hydrologique et trophique qui caractérise la mare de Bata- } \\
\text { mani a un effet limitant vis-à-vis de la disponibilité et de la qualité des ressources } \\
\text { nutritives chez les deux espèces de tilapias (O. niloticus et } S \text {. galilaeus) tandis que } \\
C \text {. citharus semble s'accommoder de la qualité de la nourriture disponible, et ce } \\
\text { quelle que soit la saison. }\end{array}$ \\
\hline
\end{tabular}

\section{INTRODUCTION}

The Inner Niger Delta is a large wetland in the Sahelian area of Mali (West Africa). Besides the Niger River itself and its floodplains, these wetlands feature numerous ponds and lakes whose characteristics are largely tied to the river's annual flooding patterns (Arfi, 2002; Orange et al., 2002). Batamani is a shallow pond in the floodplain near Mopti, seasonally connected by a short channel to the Niger River during the flood (Figure 1). Both the hydrological and biological functions of this water body are controlled by the river's annual flooding patterns (Diarra, 1999), allowing water exchange and flooding across a large area. Among the consequences of this event, macrophyte proliferation is the main ecological feature observed. This process, initiated during the flood, develops its effects over several months in the low-water period corresponding to the dry season. In contrast, during this low-water period, the water column is characterized by high turbidity and low nutritive potential, while the algal communities show low abundance (Arfi, unpublished data). One consequence of this low planktonic productivity could therefore be to limit the trophic transfer towards high-level consumers. Another perceptible effect is the biomass fluctuation of the resources available for these trophic levels, as dictated by bottom-up control theory (McQueen et al., 1986). This hypothesis has been applied to many lakes, highlighting a positive relation between the nutritive resources and indigenous fishes (Lazzaro and Lacroix, 1995; Figueredo and Giani, 2005). The last 20 years have seen a significant drop in fish numbers captured in Batamani Pond (Benech, unpublished data) and the Inner Niger Delta (Laë, 1997). This situation, similar to the general pattern in Malian fisheries, is linked to environmental changes, and has had major repercussions on the economies and populations of the Inner Niger Delta for which these water bodies are the major fish supply sources (Niaré et al., 2000). Although drought and overexploitation 


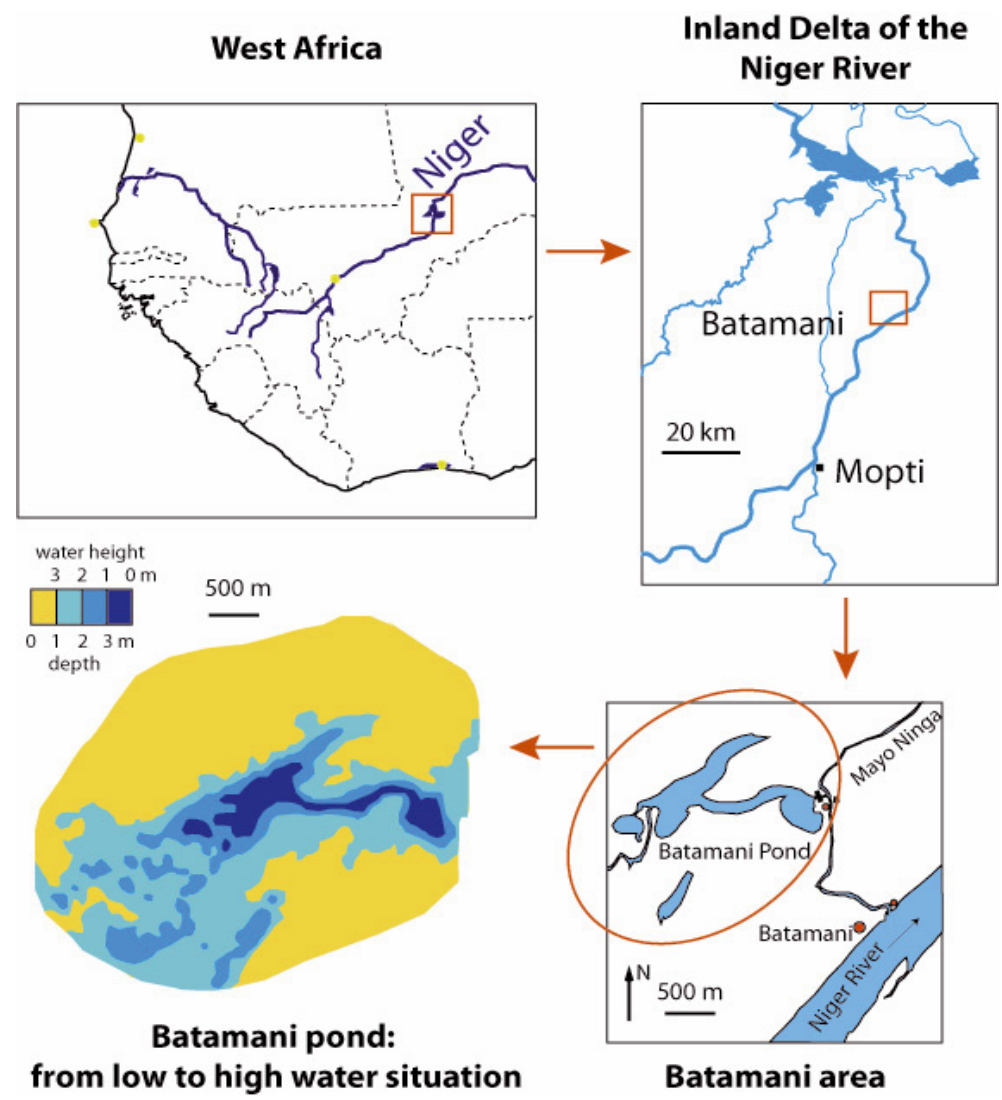

Figure 1

Location of Batamani Pond in the Inner Delta of the Niger River (Mali, West Africa).

Figure 1

Localisation de la mare de Batamani dans le delta intérieur du Niger (Mali, Afrique de l'Ouest).

can partly explain this reduction in catches, the decrease in wetland production could also result from disturbances to trophic flows or to the ability of fish to consume the naturally available food resources in a context of highly variable trophic quality (Bowen, 1982, 1988). A field study was carried out in Batamani Pond during both the dry and wet seasons in order to understand the real nutritive potential of this water body better and assess its impact on fish production. The secondary objective of this study was to understand how the marked seasonal variation observed in this area influences the nutritive characteristics of the natural foods of the tilapia Oreochromis niloticus, the main fish species of the Inner Niger Delta, and of two other omnivorous species: Sarotherodon galilaeus and Citharinus citharus.

\section{MATERIALS AND METHODS}

\section{> STUDY SITE}

The survey area is located near Mopti (central Mali, West Africa), in the Inner Niger Delta (Figure 1). It is roughly situated between Djenné to the south and Timbuktu to the north. This semi-arid Sahelian zone is characterized by a tropical climate featuring high interannual rainfall variability. South of the Sahara Desert, the Inner Niger Delta globally spans floodplains and the associated grasslands, encompassing a high number of natural ponds. Near Mopti, precipitation ranges from 400 to $750 \mathrm{~mm}$, distributed mainly over the four months from June to September. The dry season (December to May) is characterized by extremely low rainfall, and 


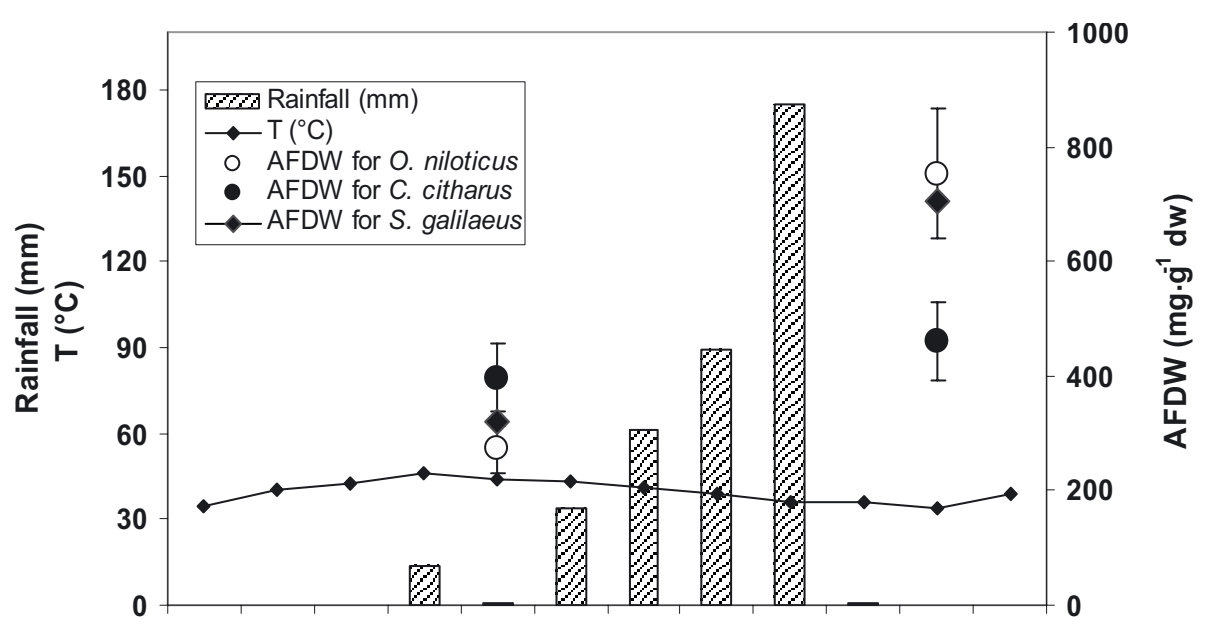

Jan. Feb. Mar. Apr. May Jun. Jul. Aug. Sep. Oct. Nov. Dec.

\section{Figure 2}

Relationship between rainfall, air temperature and level of ash-free dry weight (AFDW) in the food of O. niloticus, S. galilaeus and C. citharus in Batamani Pond for the dry season and the wet season.

\section{Figure 2}

Relation entre la pluviométrie, la température de l'air et le contenu en matière organique de la nourriture ingérée par $O$. niloticus, $S$. galilaeus et $C$. citharus en saisons sèche et humide dans la mare de Batamani.

primarily under the influence of the Harmattan, a dry and cool NE trade wind. Annual potential evapotranspiration (ETp) is eight times higher than rainfall (Figure 2). Batamani $\left(14^{\circ} 53 \mathrm{~N}\right.$, $\left.4{ }^{\circ} 2.48 \mathrm{~W}\right)$ is a shallow pond that covers a maximum area of 700 ha during the Niger River flood (July-December), a phenomenon featuring high interannual variability in duration, intensity and flow. The pond is fed primarily by a channel located in its eastern part. This channel communicates with the Mayo Ninga, a short tributary of the Niger River (Figure 1). A secondary communication channel is offered through the Shio, a natural channel in the West of the pond that connects with the Mayo Kobossi, another tributary of the Niger. Several hydrological phases can be identified in the pond. The rise in water level begins from August to September by a progressive phase induced by local rainfall; it is followed by a rapid and generalized rise step in October and November, when the Niger River floods. From December to March, the water level decreases slowly before accelerating between April and July under the combined effects of drought and evaporation. At the close of the dry season, Batamani is a small residual water body of less than 20 ha and a depth of just a few dozen $\mathrm{cm}$.

\section{> SAMPLING AND MEASUREMENTS}

Two sampling surveys were carried out in 1996, one during the dry season (May) and another during the wet season (November). For each sampling season, surveys were carried out during a day of fishing activities to assess fish stomach and intestinal contents, food characteristics, and environmental conditions at the fishing site, in order to collect data on transparency, total suspended solids in water, and nutrient concentrations.

\section{Fieldwork}

Water transparency was estimated using a Secchi disk. Water was collected at a depth of $-0.5 \mathrm{~m}$ using a Niskin bottle, and was processed immediately. Water samples for nutrient 
analysis were filtered on Whatman GF/F filters and poisoned with $\mathrm{HgCl}_{2}$. Fish were captured with a conical cast-net equipped with lead weights, and immediately dissected in order to collect the stomach and the last ten centimeters of the intestine. Samples were preserved in $10 \%$ formalin.

\section{Laboratory work: water processing}

Total suspended solids (TSS) were assessed after filtration of one liter of water on Whatman GF/F filters (pore size: $\sim 0.7 \mu \mathrm{m}$ ), previously burned $\left(550{ }^{\circ} \mathrm{C}\right.$ ) and weighed. After filtration, the filters were dried at $105^{\circ} \mathrm{C}$ for 24 hours and weighed to record TSS weight. The filters were then burned again in a furnace at $550{ }^{\circ} \mathrm{C}$ for 4 hours and weighed, giving the TSS mineral content, and by difference, the proportions of organic and mineral matter.

Nutrient analysis gave concentrations of dissolved inorganic nitrogen $\left(\mathrm{NO}_{2}-\mathrm{N}, \mathrm{NO}_{3}-\mathrm{N}\right.$ and $\left.\mathrm{NH}_{4}-\mathrm{N}\right)$ and reactive phosphorus $\left(\mathrm{PO}_{4}-\mathrm{P}\right)$ as an estimate of the potential trophic capacity of the pond in terms of primary producers. Measurements were conducted in the lab on a Technicon Autoanalyzer TA II system, following the procedure described by Strickland and Parsons (1968).

\section{Laboratory work: fish processing}

Stomach and intestinal contents were separated from their respective envelopes and treated in a drying oven at $105{ }^{\circ} \mathrm{C}$ until a constant weight was obtained. Measurements were then conducted to determine the stomach and intestinal contents in terms of total organic matter (ash-free dry weight, AFDW), fiber and total amino acids. The energy value was also assessed. The numbers of fish analyzed for each species studied and for each season sampled are given Table I. The stomach contents were considered in this study as all food consumed by the fish.

- Chemical analyses were conducted using the procedures set out by Buddington (1980). For each sample, an aliquot of approximately $30 \mathrm{mg}(\mathrm{A})$ placed in a tube was hydrolyzed with glacial acetic acid (80\%) and concentrated nitric acid (20\%). The mixture was boiled for 40 minutes at $125{ }^{\circ} \mathrm{C}$ in a heating unit, then left to cool before being recovered on Whatman GF/C filters (pore size: $\sim 1.2 \mu \mathrm{m}$ ), previously burned at $550{ }^{\circ} \mathrm{C}$ and weighed (B). The filter was successively rinsed with toluene, diethyl ether and $70 \%$ ethanol, then dried at $105{ }^{\circ} \mathrm{C}$ for 30 minutes and weighed $(\mathrm{C})$ and then burned in a furnace at $550{ }^{\circ} \mathrm{C}$ for 30 minutes and reweighed (D). Weights for organic matter (both hydrolyzable (HOM) and hydrolysis-resistant (HROM)) and mineral particle (Min) assessments were deduced from the following formulas:

Percentage of ash-free dry weight (\%AFDW): $[A+B-D] / A$

Percentage of hydrolysis-resistant organic matter (\%HROM): [C - D]/A

Percentage of hydrolyzable organic matter (\%HOM): \%AFDW - \%HROM

Percentage of mineral matter (\%Min): [D - B]/A.

- Measurement of total amino acids was performed according to Allen's procedure (1981), based on alkaline hydrolysis $(\mathrm{NaOH} 10 \mathrm{~N}$ ) in an autoclave (Lequeux Dourdan, 20 minutes at $121^{\circ} \mathrm{C}$ ) of a $12-\mathrm{mg}$ subsample. The mixture was then neutralized with glacial acetic acid. After addition of ninhydrin reagent, an aliquot fraction was placed for 20 minutes in a heating unit at $105^{\circ} \mathrm{C}$. This same operation was repeated on a standard liquid made from a solution of bovine serum albumin $\left(400 \mu \mathrm{g} \cdot \mathrm{L}^{-1}\right)$. After addition of $\mathrm{N}$-propanol $(50 \%)$, optical density was measured at $570 \mathrm{~nm}$ using a Beckman DU-64 spectrophotometer.

- The amount of energy in $10 \mathrm{mg}$ of subsample was determined for each sample using a Phillips calorimetric bomb. 


\section{Table I}

Seasonal averages and standard deviations (sd) of the nutritional characteristics of food ingested by Oreochromis niloticus, Sarotherodon galilaeus and Citharinus citharus in Batamani Pond during the dry and wet seasons. Mann-Whitney rank sum test for comparisons of averages (ns: non-significant; ${ }^{*} P<0.05$; ${ }^{* *} P<0.01$; $\left.{ }^{* *} P<0.001\right)$. $n$ : number of fish analyzed for each species.

\section{Tableau I}

Valeurs moyennes des caractéristiques nutritionnelles de la nourriture ingérée par Oreochromis niloticus, Sarotherodon galilaeus et Citharinus citharus dans la mare de Batamani en saisons sèche et humide. Comparaison des moyennes à l'aide du test non paramétrique de Mann et Whitney (ns : non significatif $\left.{ }^{*} P<0.05 ;{ }^{* *} P<0.01 ;{ }^{* *} P<0.001\right) . n$ : nombre de poissons analysés pour chaque espèce.

\begin{tabular}{|c|c|c|c|c|c|c|c|c|}
\hline \multirow[t]{2}{*}{ Species } & \multirow[t]{2}{*}{ Nutritional characteristics } & \multicolumn{3}{|c|}{ Dry season } & \multicolumn{3}{|c|}{ Wet season } & \multirow[t]{2}{*}{ Difference } \\
\hline & & Average & sd & $n$ & Average & sd & $n$ & \\
\hline \multirow{9}{*}{$\begin{array}{l}\text { Oreochromis } \\
\text { niloticus }\end{array}$} & TAA $\left(\mathrm{mg} \cdot \mathrm{g}^{-1} \mathrm{dw}\right)$ & 65.8 & 12.6 & 5 & 130.4 & 44.3 & 7 & * \\
\hline & TAA $\left(\mathrm{mg} \cdot \mathrm{g}^{-1}\right.$ AFDW) & 87.4 & 16.8 & 5 & 479.4 & 165.3 & 7 & * \\
\hline & $\mathrm{GE}\left(\mathrm{kJ} \cdot \mathrm{g}^{-1} \mathrm{dw}\right)$ & 8.1 & 5.3 & 5 & 8.5 & 9.6 & 7 & ns \\
\hline & DC for AFDW (\%) & 21.1 & 19.3 & 5 & 51.5 & 29.1 & 7 & * \\
\hline & DC for TAA (\%) & 48.9 & 13.7 & 5 & 67.7 & 10.5 & 7 & ns \\
\hline & DC for energy (\%) & 81.2 & 11.6 & 5 & 62.5 & 24.3 & 7 & * \\
\hline & DTAA $\left(\mathrm{mg} \cdot \mathrm{g}^{-1} \mathrm{dw}\right)$ & 32.1 & 5.7 & 5 & 88.3 & 26.8 & 7 & $\overline{\star \star \star}$ \\
\hline & $\mathrm{DE}\left(\mathrm{kJ} \cdot \mathrm{g}^{-1} \mathrm{dw}\right)$ & 6.5 & 7.0 & 5 & 5.3 & 11.2 & 7 & ns \\
\hline & DTAA/DE $\left(\mathrm{mg} \cdot \mathrm{kJ}^{-1}\right)$ & 4.9 & 6.8 & 5 & 16.7 & 8.9 & 7 & 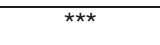 \\
\hline \multirow{9}{*}{$\begin{array}{l}\text { Sarotherodon } \\
\text { galilaeus }\end{array}$} & TAA $\left(m g \cdot g^{-1} d w\right)$ & 61.5 & 18.6 & 6 & 116.3 & 40.7 & 6 & * \\
\hline & TAA $\left(\mathrm{mg} \cdot \mathrm{g}^{-1}\right.$ AFDW) & 94.7 & 41.3 & 6 & 449.3 & 146.7 & 6 & $\star \star$ \\
\hline & GE $\left(k J \cdot g^{-1} d w\right)$ & 8.2 & 4.7 & 6 & 6.4 & 5.9 & 6 & ns \\
\hline & DC for AFDW (\%) & 32.0 & 19.9 & 6 & 58.1 & 23.8 & 6 & ns \\
\hline & DC for TAA (\%) & 54.9 & 13.7 & 6 & 76.5 & 15.5 & 6 & * \\
\hline & DC for energy (\%) & 78.2 & 15.7 & 6 & 67.3 & 22.6 & 6 & * \\
\hline & DTAA $\left(\mathrm{mg} \cdot \mathrm{g}^{-1} \mathrm{dw}\right)$ & 33.7 & 7.2 & 6 & 88.9 & 16.3 & 6 & 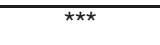 \\
\hline & $\mathrm{DE}\left(\mathrm{kJ} \cdot \mathrm{g}^{-1} \mathrm{dw}\right)$ & 6.4 & 3.1 & 6 & 4.3 & 2.7 & 6 & * \\
\hline & DTAAVDE $\left(\mathrm{mg} \cdot \mathrm{kJ}^{-1}\right)$ & 5.2 & 7.3 & 6 & 20.7 & 11.5 & 6 & *夫 \\
\hline \multirow{9}{*}{$\begin{array}{l}\text { Citharinus } \\
\text { citharus }\end{array}$} & TAA $\left(m g \cdot g^{-1} d w\right)$ & 48.6 & 23.2 & 6 & 55.5 & 13.1 & 5 & ns \\
\hline & TAA $\left(\mathrm{mg} \cdot \mathrm{g}^{-1} \mathrm{AFDW}\right)$ & 65.3 & 30.3 & 6 & 85.6 & 20.4 & 5 & ns \\
\hline & Gross energy $\left(\mathrm{kJ} \cdot \mathrm{g}^{-1} \mathrm{dw}\right)$ & 7.9 & 2.8 & 6 & 9.3 & 1.7 & 5 & ns \\
\hline & DC for AFDW (\%) & 45.3 & 24.2 & 6 & 36.5 & 30.1 & 5 & ns \\
\hline & DC for TAA (\%) & 57.1 & 14.3 & 6 & 64.3 & 25.6 & 5 & ns \\
\hline & DC for energy (\%) & 30.6 & 13.7 & 6 & 38.6 & 14.2 & 5 & ns \\
\hline & DTAA $\left(\mathrm{mg} \cdot \mathrm{g}^{-1} \mathrm{dw}\right)$ & 27.7 & 17.1 & 6 & 35.7 & 16.6 & 5 & ns \\
\hline & $\mathrm{DE}\left(\mathrm{kJ} \cdot \mathrm{g}^{-1} \mathrm{dw}\right)$ & 2.4 & 1.1 & 6 & 3.6 & 0.9 & 5 & ns \\
\hline & DTAA/DE $\left(\mathrm{mg}^{\prime} \cdot \mathrm{kJ}^{-1}\right)$ & 11.5 & 10.6 & 6 & 9.1 & 7.3 & 5 & ns \\
\hline
\end{tabular}

AFDW: ash free dry weight; TAA: total amino acid; GE: gross energy; DC: digestibility coefficients; DTAA: digestible TAA; DE: digestible energy; dw: dry weight.

- The apparent digestibility coefficient (ADC) was calculated for the various parameters (hydrolyzable organic matter and proteins) according to Conover (1966), using minerals as reference material:

$$
\operatorname{ADC}(\%)=100 \times \frac{\left(\frac{N_{s}}{M_{s}}-\frac{N_{i}}{M_{i}}\right)}{\left(\frac{N_{s}}{M_{s}}\right)}
$$




\section{Table II}

Environmental factors and suspended solids measured in Batamani Pond during the dry and wet seasons.

\section{Tableau II}

Paramètres environnementaux et caractéristiques chimiques des matières en suspension dans la mare de Batamani pendant les saisons sèche et humide.

\begin{tabular}{|c|c|c|}
\hline Parameters & Dry season & Wet season \\
\hline \multicolumn{3}{|l|}{ Environmental factors } \\
\hline Water level $(\mathrm{cm})$ & 60 & 347 \\
\hline Secchi disk values (m) & 0.1 & 0.8 \\
\hline Chlorophyll a $\left(\mathrm{mg} \cdot \mathrm{m}^{-3}\right)$ & 27.3 & 3.0 \\
\hline $\mathrm{P}^{-\mathrm{PO}_{4}}\left(\mu \mathrm{g} \cdot \mathrm{L}^{-1}\right)$ & 6.5 & 5.6 \\
\hline $\mathrm{N}-\mathrm{NH}_{4}\left(\mu \mathrm{g} \cdot \mathrm{L}^{-1}\right)$ & 63.6 & 40.8 \\
\hline $\mathrm{N}-\mathrm{NO}_{2}\left(\mu \mathrm{g} \cdot \mathrm{L}^{-1}\right)$ & 7.8 & 1.4 \\
\hline $\mathrm{N}-\mathrm{NO}_{3}\left(\mu \mathrm{g} \cdot \mathrm{L}^{-1}\right)$ & 18.9 & 1.4 \\
\hline \multicolumn{3}{|c|}{ Suspended solid constituents } \\
\hline Total dry weight $\left(\mathrm{mg} \cdot \mathrm{L}^{-1}\right)$ & 748.8 & 11.8 \\
\hline Organic material (\%) & 15.3 & 54.2 \\
\hline Mineral material (\%) & 84.7 & 45.8 \\
\hline
\end{tabular}

with

${ }^{*} \mathrm{~N}_{\mathrm{S}}$ and $\mathrm{N}_{\mathrm{i}}$ : organic concentrations (hydrolyzable organic matter and proteins) of the stomach and intestinal contents, respectively;

${ }^{*} M_{\mathrm{s}}$ and $\mathrm{M}_{\mathrm{i}}$ : mineral concentrations of the stomach and intestinal contents, respectively.

\section{RESULTS}

\section{> ENVIRONMENTAL CHARACTERISTICS}

In the dry season, the water level was very low ( $0.6 \mathrm{~m}$ during the sampling period), as was the Secchi disk value $\left(0.1 \mathrm{~m}\right.$, Table II). The very high TSS load (average: $749 \mathrm{mg} \cdot \mathrm{L}^{-1}$ ) was mainly composed of mineral matter (85\%). During the wet season, the depth of Batamani pond was $>3.5 \mathrm{~m}$. Water transparency increased markedly (Secchi disk value: $0.8 \mathrm{~m}$ in the wet season), inducing more favorable conditions for phytoplankton activity. Consequently, nutrient concentrations decreased rapidly, and dissolved mineral nitrogen was almost depleted. During this period, TSS values were low, with similar proportions of organic and mineral materials. Concentrations of dissolved inorganic nitrogen in the water column were higher during the dry season than the wet season, whereas there was no significant difference in orthophosphates between the two periods (Table II).

\section{> SEASONAL VARIATION IN THE NUTRITIVE QUALITY OF THE INGESTED FOOD}

Analysis of chemical composition showed that the diets of Oreochromis niloticus and Sarotherodon galilaeus were characterized by low amounts of organic matter during the dry season. These values were two-fold higher $(P<0.05)$ during the wet season (Figures 2 and 3 ). During this wet period, HOM levels increased significantly and constituted nearly $65 \%$ of food ingested. In contrast, organic matter contents in the diet of Citharinus citharus showed little seasonal variation. HROM levels remained stable between seasons, whatever the species, although there were larger quantities in the diet (10\% of the dry weight) of Oreochromis niloticus. The proportions of minerals in the available food followed an inverse seasonal trend to AFDW, with significantly high amounts during the dry season for O. niloticus (73\%) and 


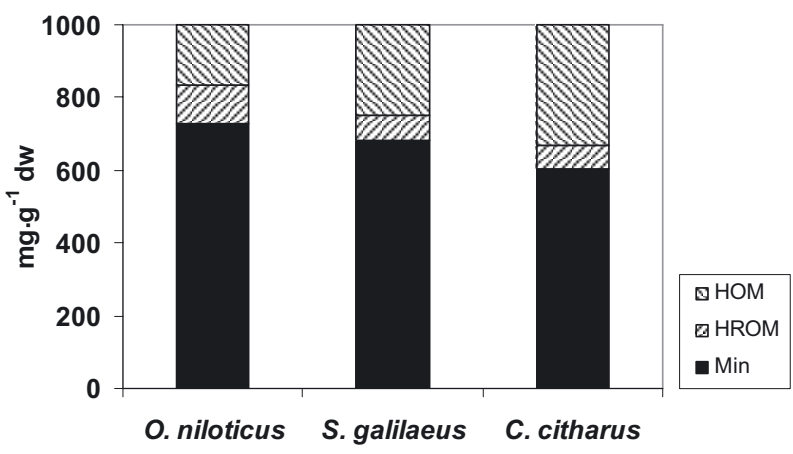

b

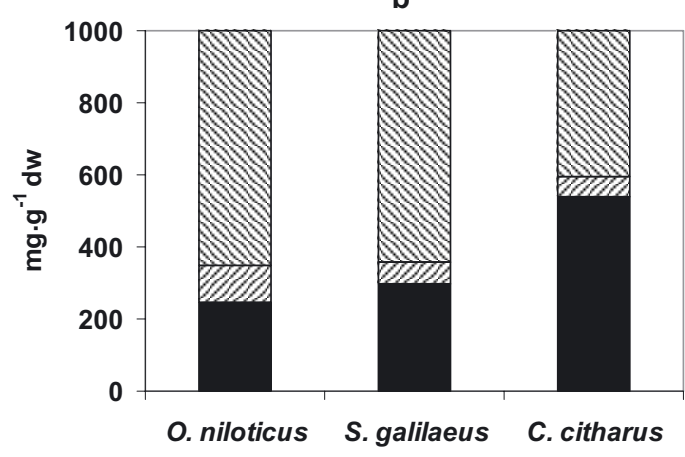

Figure 3

Seasonal change in diet composition as shown by hydrolyzable organic matter (HOM), hydrolysisresistant organic matter (HROM) and mineral matter (Min) in the stomach contents of Oreochromis niloticus, Sarotherodon galilaeus and Citharinus citharus during the dry (a) and wet (b) seasons in Batamani Pond.

\section{Figure 3}

Variation saisonnière de la composition des constituants en matière organique hydrolysable, matière organique résistante à l'hydrolyse et en minéraux de la nourriture ingérée par Oreochromis niloticus, Sarotherodon galilaeus et Citharinus citharus en saisons sèche et humide dans la mare de Batamani.

S. galilaeus (68\%). Citharinus citharus also consumed food with high amounts of mineral matter, but in comparable proportions over the two periods (Figure 3). Therefore, the chemical composition of the food consumed by this species showed low seasonal variability. However, the diet of $O$. niloticus and $S$. galilaeus was mainly dominated by digestible matter $(65 \%$ of $\mathrm{dw}$ ) during the wet season, whereas non-digestible components constituted a large proportion of their food during the dry season (HROM and minerals accounting for $75 \%$ and $84 \%$, respectively, of the total dry weight of the gut contents in $O$. niloticus and S. galilaeus).

Table I summarizes the nutritional characteristics results for the studied species. The table shows that the seasonal variation significantly modifies $(P<0.05)$ the nutritive value of the food ingested by $O$. niloticus and $S$. galilaeus and its digestibility. This food was characterized by very low total amino acid content. Amino acid concentrations (12 to $13 \%$ of dw) were two times higher during the wet season than the dry season. For $C$. citharus, total amino acids represented less than $6 \%$ of dry matter intake during the two periods, but the food eaten by this species appeared to provide a higher energy content than the food ingested by the two other tilapia species.

Concerning the digestive fate of the nutrients, the coefficients calculated for total amino acids were overall higher than for the remainder of the organic matter. For O. niloticus and S. galilaeus, the digestibility coefficients of AFDW, amino acids and energy increased significantly during the wet season (Table I). In contrast, for $C$. citharus, there was no seasonal 
variability in nutrient digestibility or energy. During the dry season, $C$. citharus showed more efficient use of organic matter (45\%) than the two other species. Hence, while the food ingested by all three species in the dry season provided almost the same amount of digestible amino acids, during the wet season, $O$. niloticus and $S$. galilaeus ingested two-fold more digestible amino acids $\left(88 \mathrm{mg} \cdot \mathrm{g}^{-1} \mathrm{dw}\right.$ ) than $C$. citharus. The protein/energy ratios of the ingested food showed high between-species and between-season variability. These protein/energy ratios were low for $O$. niloticus and $S$. galilaeus during the dry season and increased considerably in the wet season (17 and $21 \mathrm{mg} \cdot \mathrm{kJ}^{-1}$, respectively), whereas for $C$. citharus the $P / E$ ratio was not significantly different between the two seasons (Table I).

\section{DISCUSSION}

Batamani Pond is under the influence of various environmental factors. The study of prevailing hydrobiological characteristics associated with analysis of nutritive indicators in the stomach contents showed that these factors can influence fish diet, both qualitatively and quantitatively modifying the available nutritive resources. Although the three fish species studied in the pond have a comparable food regime based on plankton and detritus with limited alternatives (Lauzanne, 1976; Paugy, 1994), our results show that the chemical composition of the food ingested by $O$. niloticus and $S$. galilaeus differs considerably from the diet of $C$. citharus. The chemical composition of the food ingested by these two tilapia species was characterized by a very strong seasonal variation that could be linked to the availability of nutritive resources, which are directly dependent on environmental conditions.

During the dry season, the stomach contents of $O$. niloticus and $S$. galilaeus presented a small amount of total organic matter ( $27 \%$ and $32 \%$, respectively), partly due to the lack of organic material (15\%) in the total suspended solids (TSS), which is one of the main food sources for these fishes. The high nutrient concentrations recorded for this period indicate a low use of this resource by the phytoplankton in an environment that became unfavorable to its development. This situation stems from the very low water levels (residual height of $0.6 \mathrm{~m}$ during the sampling period) consecutive to intense evaporation, lack of rains, and the decreasing level of the Niger River. The influence of regular winds favoring water mixing drives significant sediment resuspension in this very shallow water body that consequently becomes highly turbid (transparency $\sim 6 \mathrm{~cm}$ ). TSS loads were very high (average: $749 \mathrm{mg} \cdot \mathrm{L}^{-1}$ ) and mainly composed of mineral matter (85\%). This explains the poverty of the water column in terms of nutritive resources of pelagic origin. The high concentrations of inorganic materials in the stomach contents confirm the low trophic potential of the pond during this period.

During the wet season, the more favorable ecological conditions (rise in water level, greater water transparency) drive the lateral migrations (from the river to the ponds) so decisive to fish survival (Benech and Penaz, 1995). During this flood season, the floodplain is inundated, triggering the mobilization and availability of the nutritive reserves that had accumulated in the pond sediment. The low concentrations of dissolved nutrients suggest they are assimilated by phytoplankton. The development of the food web through the appearance of aquatic fauna (insects, microcrustaceans, zooplankton) and the associated flora (immersed rooted macrophytes and helophytes) is at the origin of the increased quantities of organic matter in the TSS (54\%) and in the stomach contents of the studied species (75 and $70 \%$ of the total $\mathrm{dw}$ for $\mathrm{O}$. niloticus and $S$. galilaeus, respectively). These observations show that quantities of ingested organic matter seem to increase when the fish have a wider food spectrum, although the marked seasonality characterizing the pond has a limiting effect on the availability and quality of nutritive resources for these species. This also implies that $O$. niloticus and S. galilaeus may adapt their feeding habits to the dominant resources available and show high food plasticity, as suggested by Paugy (1994). Paugy's work on the trophic structure of the fish communities living in environments similar to Batamani Pond shows that the quality of the ingested food is related to the availability and the nature of the food resources.

In contrast to the patterns observed for the two tilapia species, the food ingested by C. citharus presents little variation in chemical composition and would therefore appear to 
be relatively unaffected by seasonal change (Table I). Contrary to O. niloticus and S. galilaeus, the quantity of digestible materials in $C$. citharus food remains constant, even during the period characterized by abundant trophic resources. This suggests that this species does not use the resources freshly introduced into the water body during the wet season. This also suggests that $C$. citharus demonstrates low food plasticity compared with the two other studied species that are more opportunistic in terms of the chemical nature of their stomach contents, which depends on the resources available and varies according to season. This specificity of C. citharus could be explained by its detritivorous feeding habits. Indeed, detritus appears to form an important source of permanently available food that often contributes to the stability and maintenance of trophic relationships in aquatic environments (Moore et al., 2004). This seems to be the case in Batamani Pond, where pelagic resources (whose productivity is conditioned by hydrological factors) rarefy during the dry season, whereas the massive presence of macrophytes and helophytes in the medium during the rainy season favors the accumulation of organic matter of detrital origin. This detrital organic matter is bound to the sedimentary compartment and remains stable and available in the pond (Eyualem and Getachew, 1992; Moore et al., 2004). However, the food derived from detrital organic matter has a variable nutritive value and its chemical composition is characterized by the presence of a high quantity of indigestible compounds such as cellulose, lignin and chitin (Bowen et al., 1995; Moore et al., 2004). This would explain the high proportions of non-digestible components (59\% to $67 \%$ of $d w$ in the dry and wet seasons, respectively) in the stomach contents of $C$. citharus. The low protein content, i.e. less than $10 \%$ of the organic matter, confirms the deficit of supply of digestible compounds (Blé et al., 2007). However, the proteins/energy ratio measured in the diet (11 and $7 \mathrm{mg} \cdot \mathrm{kJ}^{-1}$, in the dry and wet seasons, respectively) falls within the range of values capable of supporting tilapia growth (Bowen, 1982). Furthermore, the digestibility coefficients of the organic matter and proteins were higher in the diet of $C$. citharus than O. niloticus and S. galilaeus during the dry season, whereas in the wet season there was no between-species difference in dietary protein digestibility. This could mean that $C$. citharus is able to meet its food needs despite the strong mineral matter load. This trophic behavior could be a physiological adaptation of this fish, enabling it to optimize sustainability in the highly variable trophic conditions encountered in the water body. Many other fish species demonstrate adaptability to severe environmental conditions (Paugy, 1994).

In the case of $O$. niloticus and $S$. galilaeus, the nutritive quality of the food deteriorates between the wet and the dry seasons. Both species switch from a food featuring P/E ratios likely to support their growth (17 and $21 \mathrm{mg} \cdot \mathrm{kJ}^{-1}$ ) to a poor-quality food presenting below-optimal $\mathrm{P} / \mathrm{E}$ ratios $\left(25 \mathrm{mg} \cdot \mathrm{kJ}^{-1}\right)$, as suggested by Bowen (1982). In this study, these ratios measured during the dry season characterize the ingested food as protein- and energy-deficient in a context of low availability of digestible organic matter. This is confirmed by the low digestive use of organic matter and proteins during the dry season and by the high digestibility index of these two nutrients for O. niloticus and S. galilaeus during the wet season. Thus, in Batamani Pond, the wet season is characterized by the availability of high-quality food that both quantitatively and qualitatively favors the development of O. niloticus and $S$. galilaeus. This seasonal variability in nutritive characteristics was also observed for $O$. niloticus in Ziway and the Langano lakes in Ethiopia (Eyualem and Getachew, 1992; Tadesse, 1999). Although the $\mathrm{P} / \mathrm{E}$ ratio provided by the food ingested by this fish during the dry season is far below that measured in other environments, the digestive yields in proteins and organic matter are nevertheless comparable with those measured for the same species in other Ethiopian lakes (Getachew, 1987, 1993).

\section{REFERENCES}

Allen G., 1981. Methods for detection of peptides. In: Work T.S. and Burdon R.H. (eds.), Laboratory techniques in Biochemistry and Molecular, North-Holland publications, New York, 135-160.

Arfi R., 2002. Processus d'édification des ressources naturelles en zones inondables tropicales. In: Orange D., Arfi R., Kuper M., Morand P. and Poncet E. (eds.), Gestion intégrée des ressources 
naturelles en zones inondables tropicales, IRD Éditions, collection Colloques et Séminaires, 169178.

Benech V. and Penaz M., 1995. An outline on lateral fish migrations within the Central Delta of the Niger River, Mali. Hydrobiologia, 303, 149-157.

Blé M.C., Arfi R., Yéboua A.F. and Diopoh K.J., 2007. Qualité nutritive de l'alimentation naturelle du tilapia Oreochromis niloticus en élevage extensif dans des étangs de barrage (Côte d'Ivoire). Bull. Fr. Pêche Piscic., 385, 1-16.

Bowen S.H., 1982. Feeding digestion and growth - Qualitative consideration. In: Pullin R.S.V. and Lowe Mc Connell R.H. (eds.), The biology and culture of tilapias, ICLARM Conf. proceedings, 7, Manila, 141-156.

Bowen S.H., 1988. Detritivory and herbivory. In: Lévêque C., Bruton M.N. and Ssentongo G.W. (eds.), Biologie et écologie des poissons d'eau douce africains, Collection Travaux et documents $n^{\circ} 216$, ORSTOM, Paris, 243-247.

Bowen S.H., Lutz E.V. and Ahlgren M.O., 1995. Dietary protein and energy as determinants of food quality: trophic strategies compared. Ecology, 76, 899-907.

Buddington R.K., 1980. Hydrolysis-resistant organic matter as a reference for measurement of fish digestive efficiency. Trans. Am. Fish. Soc., 109, 653-655.

Conover R.J., 1966. Assimilation of organic matter by zooplankton. Limnol. Oceanogr., 11, 338-345.

Diarra R.A., 1999. Cycle géochimique du carbone, de l'azote et du phosphore dans un écosytème inondé : cas de la mare de Batamani (delta intérieur du Niger). Diplôme École Normale Supérieure, Université du Mali, 99 p.

Eyualem A. and Getachew T., 1992. Seasonal changes in the nutritional status of Oreochromis niloticus L. (Pisces: Cichlidae) in lake Ziway, Ethiopia. Arch. Hydrobiol., 124, 109-122.

Figueredo C.C. and Giani A., 2005. Ecological interactions between Nile tilapia (Oreochromis niloticus, L.) and the phytoplanktonic community of the Furnas Reservoir (Brazil). Freshwater Biol., 50, 13911403.

Getachew T., 1987. A study on an herbivorous fish, Oreochromis niloticus L., diet and its quality in two Ethiopian Rift Valley lakes, Awasa and Zwai. J. Fish Biol., 30, 439-449.

Getachew T., 1993. The composition and nutritional status of diet of Oreochromis niloticus in Lake Chamo, Ethiopia. J. Fish Biol., 42, 865-874.

Laë R., 1997. Effects of climatic changes and developments on continental fishing in West Africa: the examples of the Central Delta of the Niger in Mali and coastal lagoons in Togo. In: Remane K. (ed.), African inland fisheries, aquaculture and the environment, Farham, Fishing News Books, 66-86.

Lauzanne L., 1976. Régimes alimentaires et relations trophiques des poissons du lac Tchad. Cahiers ORSTOM, Série Hydrobiologie, 10, 267-310.

Lazzaro X. and Lacroix G., 1995. Impact des poissons sur les communautés aquatiques. In: Pourriot R. and Meybeck M.C. (eds.), Limnologie générale, Collection d'écologie, 25, Masson, Paris, 648-686.

McQueen D.J., Post J.R. and Mills E.L., 1986. Trophic relationships in freshwater pelagic ecosystems. Can. J. Fish. Aquat. Sci., 43, 1571-1581.

Moore J.C., Berlow E.L., Coleman D.C., de Ruiter P.C., Dong Q., Hasting A., Collins Johnson N., McCan K.S., Melville K., Morine P.J., Nadelhoffer K., Rosemond A.D., Post D.M., Sabo J.L., Scow K., Vianni M. and Wall D., 2004. Detritus, trophic dynamics and biodiversity. Ecol. Lett., 7, 584-600.

Niaré T., Kassibo B. and Lazard J., 2000. Quelle pisciculture mettre en œuvre au Mali, pays de pêche artisanale continentale ? Cahiers Agricultures, 9, 173-182.

Orange D., Mahé G., Dembélé L., Diakité C.H., Kuper M. and Olivry J.-C., 2002. Hydrologie, agroécologie et superficies d'inondation dans le delta intérieur du Niger. In: Orange D., Arfi R., Kuper M., Morand P. and Poncet E. (eds.), Gestion intégrée des ressources naturelles en zones inondables tropicales, IRD Éditions, collection Colloques et Séminaires, 209-229.

Paugy D., 1994. Écologie des poissons tropicaux d'un cours d'eau temporaire (Baoulé, haut bassin du Sénégal au Mali) : adaptation au milieu et plasticité du régime alimentaire. Revue d'Hydrobiologie Tropicale, 27, 157-172.

Strickland J.D.H. and Parsons T.R., 1968. A practical handbook of sea water analysis. Bull Fish. Res. Board Can. (Ottawa), 167, p. 311

Tadesse Z., 1999. The nutritional status and digestibility of Oreochromis niloticus L. diet in Lake Langeno, Ethiopia. Hydrobiologia, 416, 97-106. 